\title{
XXIX. On the accidents incident to steam boilers
}

\author{
John Taylor Esq. F.R.S. F.G.S. F.H.S.
}

To cite this article: John Taylor Esq. F.R.S. F.G.S. F.H.S. (1827) XXIX. On the accidents incident to steam boilers, Philosophical Magazine Series 2, 1:2, 126-133, DOI: 10.1080/14786442708674241

To link to this article: http://dx.doi.org/10.1080/14786442708674241

$$
\text { 曲 Published online: } 10 \text { Jul } 2009 .
$$

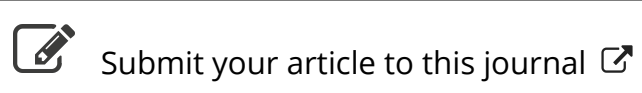

\section{山 Article views: 3}


nuper vidi sub hoc nomine inter alias rarissimas plantas in horto Dom. Tate, in vico Sloane-street.

Habitus fortè ut in C. triquetro Nob.-Flores ignoti : sed prope id locarem. St. $h$.

gracilis. C. (slender, long-spined) suberectus, teretiusculus:

10. spinis antiquis solitariis rectis uncialibus, incipientibus geminatis plúsve, albis.

Habitat in Americâ calidiore. St. $h$.

Obs. Unam plantam t-entalem virescentem simplicem apud Dom. Loddiges solùm vidi, cum duabus incipientibus ramulis recentèr pullulatis. Plantæ facies est ferè ut in Euphorbia Hystrix Auctorum, at adhuc minùs spinosa, duplò brevioribus spinis. An rami in ætate 3-angulares? Flores adhuc ignoti. Affinis fortassè Cerei nani Kunz: (quod non vidi) et prope id locarem; sed nihilominùs fortè longè major, et sine areolis; ut in Cereo nano.

P.S. Yaving, since my last communication, detected an error in my fourth Decade of New Succulent Plants, page 33, line 13, (in the Philosophical Magazine for August 1823), have the goodness to notice it as follows:

"For hæmisphericæ, read orbiculari."

XXIX. On the Accidents incident to Steam Boilers*. By JoHN TAYLor, Esq. F.R.S. F.G.S. F.H.S.

$\mathrm{T}$ has been remarked by some practical men who have had most opportunity of examining the circumstances under which the bursting of boilers has taken place, that the causes have sometimes appeared to be not of that simple character which is commonly assigned to them; and that some such accidents have occurred where neither excessive expansive force of steam, neglect of the usual precaution, weakness of material or bad construction, existed to a degree equal to the effect. $\mathrm{Mr}$. Woolf in a conversation upon this subject some time since, expressed to me his opinion of some case where, as he thought, there was ground to suspect the operation of an explosion of gas in the flues, or at least outside the boiler. Any inquiry or discussion into the causes of circumstances which continue to be a reproach to our mode of using steam, must, I conceive, be useful; and my principal object will rather be to provoke it, and to encourage a record of facts, than to propound any particular theory of my own, though I admit that some recent cases appear to countenance Mr. Woolf's idea.

In the mines of Cornwall, and in those of North Wales, the

* Communicated by the Author. 
use of high-pressure steam has become general: in the former district it is, I believe, universal, and is applied to condensing engines not differing very much from Boulton and Watt's construction, among which engines are many of enormous power, and the largest in the world. The steam is commonly so as to balance from 15 to 40 pounds on each inch of the safety-valve; and some difference of opinion exists among the engineers as to the importance of using it at a higher or lower degree of pressure.

It will be necessary to describe the boilers which have been employed, in order to understand the subject, and to notice those which have been subject to accidents; which indeed, as far as I know, have been confined to one sort of boiler,-or at least such accidents as have been attended with any fatal or distressing consequences.

This description of boiler, though appearing therefore to be the most hazardous, is yet most generally adopted; and as it is believed to have some advantages over others in other respects and under certain circumstances, it will probably continue to be generally preferred, or at least until some construction that shall unite these advantages with more perfect security may be brought into use : this, indeed, it will not be very easy to do, as the experiments on boilers have been multiplied to a great extent in Cornwall, and the expense incurred by many of the mines in this way has been so great, that but few of the managers will probably be inclined to enter upon them again without some very clear prospect of success.

The steam boilers which I mean to describe as the most common, are those which are constructed by fixing one tube within another: the interior one containing the fireplace, and the space between it and the exterior containing water, and in the upper part steam. This kind of boiler was, I believe, first introduced by Trevithic for his simple high-pressure engines: he made the outer tube of cast iron, and the inner one, which was often recurved so as to make a double circuit within, of wrought iron. At present both the tubes are made of wrought iron or rolled plates: the form is simply that of one straight tube passing through the other; the ends of the boiler fix the tubes together, so that the interior tube is open at both ends; at one of which is placed the fire-grate, and at the other the smoke and flame pass out, and are conveyed to the stack or chimney most commonly by flues passing under and along the sides of the outer case.

The following sketch will show the cross sections : they are commonly from 20 to 35 feet in length, the diameter of the inner tube from 3 to 4 feet, and of the outer one from $5 \frac{1}{2}$ 
to $6 \frac{1}{2}$ or 7 feet. The former are usually $\frac{1}{2}$ an inch thick, and the outer case $\frac{3}{8}$ ths.

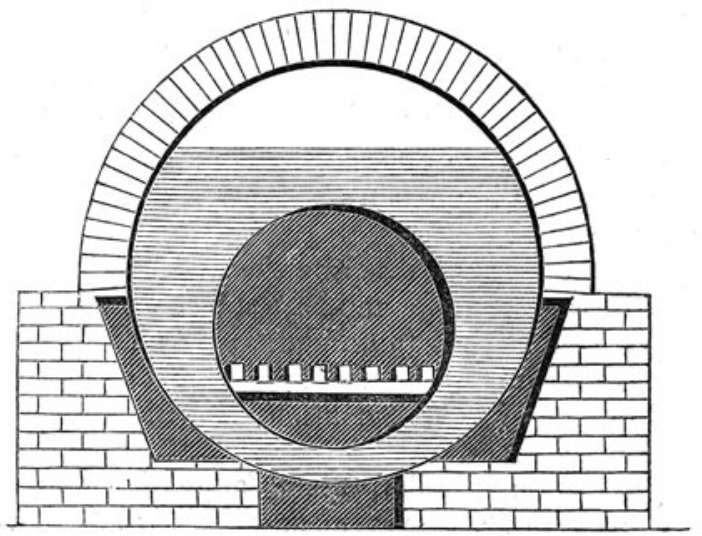

The weakest parts of this construction have generally been supposed to be, the outer tube, by having too great a diameter for the strength of iron used, and the ends of the boiler, which, by being square and riveted to angle iron, are more likely to break than if a spherical form were adopted. It does not appear, however, in practice, that these have been the first parts to give way.

The advantages which this boiler seems to possess over others may be shortly stated. It has been found, by comparing the duty of the engines by means of the monthly reports, and checking this by the observations of the agents, that the fuel goes further in them than in any others yet tried. Circumstances, at first sight apparently trivial, may perhaps conduce to this result. I suspect that the peculiarities of coal of different districts influence more the success of different kinds of boilers than has been generally supposed. In Cornwall all the coal is from South Wales, and is brought from the neighbourhood of Swansea; it is less bituminous than most other coal, is not easy to inflame, but gives a strong and durable fire: it is subject to the objection of producing a great deal of clinker, and this unites with and adheres strongly to any brick-work which the fire may come in contact with, so as to require frequent cleansing of the fireplace. In the boilers I have been describing there is no brick-work near the fire, the clinker does not adhere to the iron sides, and the process of cleansing is easy and rapid; the action of the fire is therefore regular and uninterrupted.

The second kind of boiler used is a single tube made of wrought iron plates of considerable length but of small diameter, 
meter, with ends of the same material generally of a hemispherical form; it is placed horizontally, the water occupying by far the larger portion of the space within, and the fire is applied under the bottom part.

The section annexed shows the position of the boiler with respect to the fire: the lengths which have been usually made may be stated at from 20 to 40 feet, and the diameter from 4 to 5 feet. The plates generally employed for making these boilers are

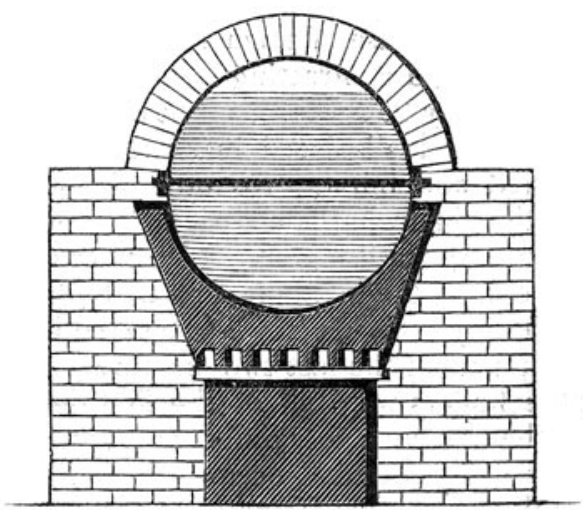

This construction is common, I believe, in America, but they were not much used in England until they were introduced by Messrs. Taylor and Martineau, who have made them in a very excellent manner; and by placing the bar across the centre, as shown in the drawing, and which is repeated at intervals throughout the whole length, they have given them the greatest strength, and rendered them easy to repair. I have never heard of any one of these boilers having burst or caused any disagreeable accident.

In our mines in North Wales $I$ have used them with great advantage, and our agents and engineers prefer them to any other, and find that they generate steam rapidly, and apparently with œeconomy; but, as there is no monthly report there as in Cornwall, this point cannot be ascertained precisely.

I expected the same advantage by using them in Cornwall, with the further one of increased security. In this I.have been disappointed: the difference in the quality of the coal appears to be the reason; -in North Wales it is a free burning and bituminous coal, and makes little or no clinker, and therefore essentially different from what I have described the coal used in Cornwall to be. With the latter these boilers do not appear to afford steam freely; whilst the brick sides of the fire-

New Series. Vol. 1. No. 2. Feb. 1827. S place 
place are so rapidly encrusted with clinker, and the door so frequently kept open to cleanse them, that much of the effect of the fire is destroyed.

The third class of boilers which have been used in the mines is that which includes Mr. Woolf's invention of a series of tubes filled with water and exposed to the fire. These boilers were the subject of one of his patents, and various descriptions of them are to be found in works which treat on these subjects. If one objection to them could be surmounted, they would probably be the best description of boilers we know of, but this has caused the use of them to be discontinued;-the tubes by expanding and contracting not only injure the joints, which must necessarily be numerous, but by sudden influences of the fire the water is displaced in some of them, and the tubes are injured and burst. No other inconvenience has occurred from this than what is occasioned by the frequent repairs thus called for; but it amounts of itself to a serious evil.

Of four accidents by the bursting of steam boilers which have come more under my notice as having occurred in mines where I am interested, and in the last two or three years, I would remark that the boilers were all of the first description. In other respects the circumstances differed very much. They were erected under the superintendence of different engineers,were made by different manufacturers in parts of the country distant from each other, of materials from various sources; they were mostly nearly new or not apparently the worse for wear, and were each furnished with a safety-valve and gauge cocks; though I admit that there is not so much attention to the care of these matters in the boiler-houses of mines as could be wished.

The first accident was at Wheal Fortune, to one of six boilers which are employed to work the large engine there of 90-inch cylinder. I do not recollect that any thing remarkable occurred to observe upon with regard to this; the injury was limited to the boiler itself, and it occasioned no particular discussion. The engineer was $\mathrm{Mr}$. Woolf.

The next was extraordinary from the circumstance of two boilers blowing up at the same moment or nearly so. This happened at Polgooth Tin Mine, where three were employed in the same house to work the engine (80-inch cylinder). The engine had been stopped a short time for some repairs to the pump-work in the shaft; but it seemed clear after the accident, by the most accurate investigation that could be made, that the steam had not acquired any formidable degree of pressure, nor was the water so low as to endanger the tube being improperly heated. The engineer was Mir. Sims, and the boilers. 
as well as the engine. were nearly new. One man, unfortunately, was killed, and the stack of the engine-house was much shattered, as well as the building itself. The interior tubes of the boilers were much contorted and rent. Captain Reed, who was near the spot, remarked, that the one explosion was heard a little before the other, but the noise had hardly ceased when the second took place.

Some time after, one of the boilers of the 64-inch cylinder engine at East Crennis Mine blew up. This engine was also under the care of Mr. Sims, but had been much longer at work than that at Polgooth. The inner tube was compressed as if the fire had softened the part above it, though there did not appear to be any other reason to think that the water was too low. The ends were torn to pieces, and the tube was. projected out of the case and out of the house, while the case itself remained in its place, and scarcely injured. No person was materially hurt.

The last accident, which has led more particularly to these remarks, happened at the Mold Mines in Flintshire, to a boiler of a similar construction; one of three working the Pen- $\hat{y}$-fron engine 66-inch cylinder, erected by Captain Francis the principal ag ent, but of late under the care of Mr. Bawden, engineer.

The outer case remained in its seat uninjured, as at East Crennis, and even the weight on the lever of the safety-valve was not disturbed; the inner tube was not moved out of its place, although it was very much flattened or compressed for a great part of its length, but in a contrary direction to that at East Crennis; the sides as it were having come together, and not the top and bottom, they approached so close to each other as to hold a brick, which it is not easy to account for being there. The part which contained the fireplace, and for some length near it, remained in the original form. The ends both here and at East Crennis presented an appearance as if they had broken the angle iron rather by the contraction of the tubes than by being pressed outwards.

Circumstances rendered it possible to get better evidence. of the state of the steam and water, \&c. than happens in most such instances; and it seemed certain that the former did not exceed a pressure of $30 \mathrm{lbs}$. an inch, and that the other was quite at its proper height. There was a lead plug indeed above the fire which would have been destroyed if it were not so.

The engine had been stopped a few minutes; the engineman had opened the fire-doors of the three boilers, and had closed the dampers of the other two: he was on this boiler, putting down the damper in the flue, which was no sooner done than he observed a gust of flame rushing from the fire- 
place, and almost immediately after an explosion, which made him jump from a door-way considerably above the level of the ground below, as the engine stands on the side of a steep hill:-this door was used to discharge the cinders from the ashpits. He alighted on the heap, and escaped out of the way just before the hot water gushed out. Two other men who were in the boiler-house were not so fortunate, and they were killed instantly by the boiling water; no mark of any other injury being to be found on their bodies.

In this case, had the rush of flame from the fireplace any thing to do with the subsequent explosion?

And admitting that the steam was so far within the pressure that could by mere expansive force regularly exerted injure such a boiler, - might not the rupture be occasioned by the aid that a vacuum suddenly created might produce?

Does not the bursting of the one boiler after another as at Polgooth, seem to indicate that exterior causes operated?

Is it possible to conceive; - supposing the pressure equal in two boilers as ivas the case at Polgooth, both being connected to the same steam-pipe,- that the relative strength of the two should be so exactly the same as that what would by mere expansive force burst the one should have the same effect upon the other?

Have not all calculation and reasoning with respect to the strength of boilers hitherto had regard merely to such expansive force uniformly exerted; and if we suspect or admit the action of concussion, or the effects that any thing like a blow would exert, ought we not to make a very different estimate in their construction?

My intention was rather to state the facts than to attempt an explanation of what is certainly at present very obscure; but that I may do all in my power to direct attention to the subject, I will venture on a supposition. At the Pen- $\hat{y}$-fron engine we see that the fire-door is thrown open, and then the current of air up the flue is stopped by closing the damper; the interior is filled with atmospheric air mixed to a certain extent with coal gas; the latter is increased by the distillatory action of the fire until the proportion is attained which is explosive; it takes fire, producing the rush of flame which worald be followed by a sudden vacuum in the tube; while the other side, pressed by the steam, gives way to this sudden impulse, and is destroyed by a force very much smaller than would be required if uniformly exerted.

By some it has been suggested that hydrogen may have been generated by the decomposition of water from leaks in the boiler. 
That sudden inflammations of gas in the chimneys of these engines does take place is, I believe, sufficiently obvious. By night it is observable that bursts of flame suddenly illuminating the surrounding scene, and rising to a considerable height above the summit of the stack, are seen to emerge, and after a blaze of some minutes diminish and retire into the flue, leaving all once more in perfect darkness. This effect I certainly do not recollect to have noticed where the coal is less bituminous. The fact is not, perhaps, of much importance; but it has been remarked upon by some who have witnessed the accident I have described, and has been discussed by them in reference to it, and therefore it is right to mention it.

Though I have been led to describe the bursting of boilers where what is called high-pressure steam has been used, I by no means think that boilers are safer because the steam in them is supposed to be limited to a lower degree of expansive force. High-pressure boilers are or ought to be very strong, and can only give way by a great increase of force beyond what they are calculated to resist, which should happen but seldom. Low-pressure boilers are from their construction very weak, and a little carelessness raises the power of the steam within them to the bursting point, and when they give way the consequences are often very fatal. Not to mention other instances, I may remark, that about twelve months since one of the old spherical construction, which is still much used in some parts of the kingdom, burst at a mine in Flintshire about 7 miles from the Mold Mines, and occasioned the death of 16 persons : it was replaced by two smaller boilers of the second kind $I$ have described, and high-pressure steam applied with good effect to the engine, and with perfect security.

XXX. On the Crystalline Forms of Wagnerite. By A. Levy, Esq. M.A. F.G.S.*

NE of the rarest species in mineralogy is that which has been named Wagnerite, the chemical composition of which according to the analysis of Fuchs it as follows:

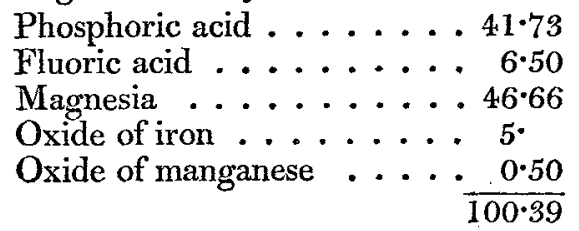

A large and well-defined crystal of this substance is preserved in Mr. Heuland's private collection, and it is the only * Communicated by the Author. 